\title{
Conflicted Identity and Colonial Adaptation in Petrus Alfonsi's Dialogus contra judaeos and Disciplina clericalis
}

The Jew who becomes a Christian does not completely break with the world of his past. He finds a new perspective, one which is cursed and abhorred by his people, but which unquestionably derives from his past. -Albert Memmi ${ }^{1}$

Converso studies have tended to focus on the $15^{\text {th }}$ and $16^{\text {th }}$ centuries, ${ }^{2}$ for that is the period most heavily documented and during which lived the greatest numbers of (firstgeneration) conversos. Also, the pace and intensity of conversion activity picked up considerably after the pogroms of 1391, again during the Disputation of Tortosa in 14121413, and once again just prior to the expulsion of the Jews from Spain in 1492. However, the converso story begins long before 1391, and high-profile converso polemicists and thinkers such as Pablo Cristiani (d. 1274), Alfonso de Valladolid (c. 1270-1340), Pablo de Santa María (c. 1350-1435), have a predecessor in Petrus Alfonsi, who died over two full centuries before 1391. Petrus Alfonsi is a forerunner of the conversos of late medieval and early modern Spain, and his experience as a converso is clearly reflected in his writings, the personal record of a man born into Andalusī Jewish society and reborn into Christian Aragon.

Although he wrote treatises on several subjects spanning from short narrative to astronomy, Petrus Alfonsi is best remembered for two works, one a religious polemic entitled Dialogus contra judaeos (=Dialogus), the other a collection of exempla and gnomic lore known as the Disciplina clericalis (=Disciplina). Formally, the Dialogus is an anti-Jewish and anti-Muslim polemic; but it is also a dramatization of the identity crisis Petrus Alfonsi experienced as a new convert to Christianity. In it, he matches wits with his past, Jewish self. By contrast, the Disciplina, as an essentially secular text (although the title bills it as a textbook for priests) is an effective and less problematic transculturation of Arabic $a d a b$ literature in the colonial setting of the (Re)conquest. Together, these works tell the story of the author's journey from the bicultural world of the Andalusī Jewish intellectual, to the conquest of his homeland and his conversion to Christianity, and into his second career as ambassador of Andalusī learning to Christian Europe.

Although he produced numerous works in Latin on a wide range of subjects both scientific and religious, ${ }^{3}$ this essay will focus on the two for which he is best known, the Disciplina Clericalis (= Disciplina), and the Dialogus Contra Judaeos (=Dialogus). The former is a collection of fables and tales drawn from Arabic and Hebrew sources that was widely copied, and today exists in 76 manuscripts. ${ }^{4}$ It introduced European audiences to

\footnotetext{
${ }^{1}$ Albert Memmi, Portrait of a Jew, trans. Judy Hyun (New York: Orion Press, 1962), 74.

${ }^{2}$ All dates given refer to the Common Era (C. E.).

${ }^{3}$ See Charles Burnett, 'The Works of Petrus Alfonsi: Questions of Authenticity,' Medium Avum 66, no. 1 (1997); Charles Homer Haskins, Studies in the History of Medieval Science (Cambridge: Harvard University Press, 1927), 113.

${ }^{4}$ John Tolan, Petrus Alfonsi and His Medieval Readers (Gainesville: University of Florida, 1993), 199-204.
} 
new stories and to new ways of telling them, and by virtue of its international popularity, exercised significant influence on the development of early European vernacular prose fiction. ${ }^{5}$ The Dialogus is a religious polemical dialogue in which Petrus Alfonsi, arguing with Moshé Sefardí, his own former, Jewish self, strives to prove the truth of Christianity logically, using the Hebrew Bible and Talmud as authoritative sources. While there is a good deal of scholarship on the Disciplina and the Dialogus regarding its textual tradition and its impact on later European authors, there is no study that considers Petrus Alfonsi's experience as a converso as primary in understanding both of these texts. ${ }^{6}$

\section{Biography}

The historical circumstances in which Petrus Alfonsi converted to Christianity were essentially colonial: his homeland was conquered by a people who imposed a new political order, new institutions, and a new official language, Latin. These changes put the following challenge to a Jewish intellectual such as Moshé Sefardí: 'these are the new rules - you don't have to agree with them, but you do have to play by them.' Petrus Alfonsi writes his rational, yet highly personal response to this challenge into the Dialogus and the Disciplina, and both are significant in understanding key elements of his experience qua converso.

Born Moshé Sefardí in the last quarter of the $11^{\text {th }}$ century, Petrus Alfonsi lived in the majority Muslim, bilingual (Romance/Colloquial Arabic) city of Wāšqa (Huesca) in Aragon. As a Jew living in al-Andalus, he would have received his secular education in Arabic, and his religious instruction in Hebrew. ${ }^{7}$ In his lifetime he was to live through Aragon's political and cultural transition from Islam to Christianity, and his life experience is emblematic of the cultural change and synthesis that characterized (Re)conquest-era Spain. He appears to have been a leader of the Jewish community of Wāšqa, and as such received a double education in classical Arabic literature, philosophy and the sciences, as well as in Hebrew and the Jewish rabbinic and literary tradition. ${ }^{8}$ In all respects he was typical of the Jewish intellectuals of his time, even down to his occupation - that of physician. He grew up in a society where the dominant religion was Islam, the official language of government and education was Classical Arabic, and the colloquial tongue either Andalusī Arabic or Romance. He is the product of the sunset of

\footnotetext{
${ }^{5}$ See Tolan, Petrus, 132-58; Petrus Alfonsi, Disciplina clericalis, ed. and trans. Ángel González Palencia (Madrid: Consejo Superior de Investigaciones Científicas (CSIC), 1948), xxiv-xxxiii.

${ }^{6}$ Hermes discusses the tradition of Jewish self-criticism, but does not address the converso. See Petrus Alfonsi, The Disciplina Clericalis of Petrus Alfonsi, ed. Eberhard Hermes, trans. P.R. Quarrie (Berkeley: University of California Press, 1977), 90-9.

${ }^{7}$ For an excellent overview of Jewish intellectual life in al-Andalus, see Ross Brann, 'The Arabized Jews,' in The Literature of Al-Andalus, ed. María Rosa Menocal, Raymond P. Scheindlin, and Michael Sells (Cambridge: Cambridge UP, 2000). On the cultural scene of medieval Aragon in particular, see Joaquín Lomba Fuentes, 'El Marco Cultural de Pedro Alfonso,' in Estudios sobre Pedro Alfonso de Huesca, ed. María Jesús Lacarra (Huesca: Instituto de Estudios Altoaragoneses, 1996).

${ }^{8}$ On the life of Petrus Alfonsi, see Tolan, Petrus, 9-11; María Lourdes Alvárez, 'Petrus Alfonsi,' in The Literature of al-Andalus, ed. Maria Rosa Menocal, Raymond P. Scheindlin, and Michael Sells (Cambridge: Cambridge University Press, 2000), 282-4.
}

Author's Postprint version. Please cite published version: Wacks, David. "Conflicted Identity and Colonial Adaptation in Petrus Alfonsi's Dialogus Contra Judaeos and Disciplina Clericalis." Marginal Voices: Studies in Converso Literature of Medieval and Golden Age Spain. Ed. Gregory B. Kaplan \& Amy Aronson-Friedman. Leiden: Brill, 2012.69-90. http://www.brill.nl/marginal-voices 
the great flowering of Andalusī Jewish intellectual culture during the $12^{\text {th }}$ century, one of the last of what Ross Brann has described as the 'courtier-rabbis,'

a most improbable breed of literati and an even more unlikely brand of clerics. On the one hand, they were deeply attached to Jewish tradition and meticulous in their observance of Jewish law; on the other, they were aficionados of Arabic paideia (cultural education) in Hebrew dress. ${ }^{9}$

In this description, Brann captures the essence of the Andalusī Jewish intellect, that ability to move between faith and science, Hebrew and Arabic, divine and temporal. Moshé Sefardí (but not Petrus Alfonsi, as we shall see) was thus able to move back and forth between two cultures, Islamic and Jewish. This Andalusī Jewish biculturality is key in understanding the work of Petrus Alfonsi. Gustavo Pérez Firmat, writing of CubanAmericans, describes this condition as follows:

biculturation designates not only contact of cultures; in addition, it describes a situation where the two cultures achieve a balance that makes it difficult to determine which is the dominant and which is the subordinate culture. [It] . . implies an equilibrium, however tense or precarious, between the two contributing cultures. [Cuban-Americans'] hyphen is a seesaw: it tilts first one way, then the other. ${ }^{10}$

What most distinguishes Petrus Alfonsi from his Jewish contemporaries is his conversion to Christianity, which gained him entrée into the highest levels of Christian society, and enabled him to refashion himself into an intellectual who participated fully in the culture of the majority (as he once was in al-Andalus). This change came at a cost: while the bicultural courtier-rabbis of al-Andalus were able to move back and forth between Muslim and Jewish cultures while still maintaining their distinct Jewish identity, the conversos inhabited a space between their Jewish and Christian identities. There is no place for Jews in Christianity, and this rejection is internalized by Petrus Alfonsi, who struggles with the memory of his Andalusī Jewish self. From the $15^{\text {th }}$ century forward, it is well documented that even when conversos were accepted as Christians, they remained marked by difference. Based on his own writings, this seems to have been true of Petrus Alfonsi as well. ${ }^{11}$ In his case, this difference propelled him to great success as a courtier and an intellectual, but the identity crisis he suffered as a converso left its mark on his writings. This crisis begins with his conversion, but no personal crisis exists outside a

\footnotetext{
${ }^{9}$ Ross Brann, The Compunctious Poet: Cultural Ambiguity and Hebrew Poetry in Medieval Spain (Baltimore: Johns Hopkins University, 1991), 9.

${ }^{10}$ Gustavo Pérez Firmat, Life on the Hyphen: the Cuban-American Way (Austin: University of Texas Press, 1994), 6.

${ }^{11}$ See Petrus Alfonsi, The Scholar's Guide, trans. Joseph R. Jones and John E. Keller (Toronto: The Pontifical Institute of Medieval Studies, 1969), 19. On racialism during inquisitorial Spain, see Henry Kamen, The Spanish Inquisition: A Historical Revision (New Haven: Yale University Press, 1998), $230-54$.
}

Author's Postprint version. Please cite published version: Wacks, David. "Conflicted Identity and Colonial Adaptation in Petrus Alfonsi's Dialogus Contra Judaeos and Disciplina Clericalis." Marginal Voices: Studies in Converso Literature of Medieval and Golden Age Spain. Ed. Gregory B. Kaplan \& Amy Aronson-Friedman. Leiden: Brill, 2012.69-90. http://www.brill.nl/marginal-voices 
social vacuum. In reading the Dialogus and the Disciplina as a record of Petrus Alfonsi's conflicted identity, we must situate the man in his times.

In the battle of Alcoraz (1096), the armies of Sancho Ramírez of Aragon (r. 10941101) overcame the forces of al-Musta 'in just outside of Huesca. ${ }^{12}$ At this time, Moshé was nearing middle age, and had lived nearly half of his life as a Jew. He fared quite well in the transition to Christian sovereignty under Pedro I (1101-1104). His medical expertise and prestigious Andalusī education afforded him access to the highest levels of society, and in a short time he was appointed royal physician at the court of the new king, Alfonso I of Aragon (r. 1104-1134). Despite his position at court, Moshé Sefardí was still a member of a religious minority in a society where this posed an insurmountable obstacle to full participation in Latin intellectual life. Jews under Christian rule did not enjoy the rights equivalent to those guaranteed to them by dhimmi status under Islam. ${ }^{13}$ Worse yet, Catholic doctrine had long held Judaism in open contempt, and any privileges granted to Jewish subjects depended on the whims of the monarch in question. ${ }^{14}$ Moshé Sefardí belonged to a class of Andalusī Jews accustomed to full participation in the intellectual life of the dominant Arabic culture. He must have anticipated that this participation would be curtailed in a Latin environment, and that the intellectual biculturality enjoyed by the courtier-rabbis would not survive the transition to Christian government. Andalusī Jews were educated in Arabic, but the Jews of Christian Spain with very few exceptions - did not learn Latin, and in their secular literary practice they gradually abandoned Arabic in favor of Hebrew. ${ }^{15}$ Accordingly, one may well speculate that Petrus Alfonsi converted in order to enjoy full participation in the intellectual life of Christian Europe, but we can never know for a certainty. Whatever his reasons, he converted to Christianity in 1106, taking the names of Saint Peter and of his godfather, none other than King Alfonso I of Aragon (r. 1104-1134). ${ }^{16}$ The Christian Petrus Alfonsi wasted no time in capitalizing on his new social status. He obtained a respectable

\footnotetext{
${ }^{12}$ Encyclopedia of Islam CD-ROM Edition, (Leiden: E. J. Brill, 2004), 'Hūdids'; Ramón Menéndez Pidal, La España del Cid, 2 vols. (Madrid: Editorial Plutarco, 1929), 2: 562-4.

${ }^{13}$ See EI, 'Ahl al-kitāb'; Yohanan Friedmann, Tolerance and Coercion in Islam: Interfaith Relations in the Muslim Tradition (New York: Cambridge University Press, 2003), 54-86; Bernard Lewis, The Jews of Islam (Princeton: Princeton University Press, 1984), 3-66.

${ }^{14}$ Renée Levine Melammed, A Question of Identity: Iberian Conversos in Historical Perspective (New York: Oxford University Press, 2004), 4. On Jews' dependence on the crown, we read in the Fuero de Teruel (ca. 1176) that the Jews of that community 'siervos son del sennor Rey et sienpre a la real bolsa son contados' ('are servants of the Lord King and are always counted among the royal assets.') See Max Gorosch, ed., El Fuero de Teruel (Uppsala: Almqvist \& Wiksells, 1950), 320.

${ }^{15}$ On the Jewish communities of Northern Spain in transition to Christian rule, see Eliyahu Ashtor, The Jews of Moslem Spain, trans. Aaron Klein and Jenny Machlowitz Klein, 3 vols. (Philadelphia: Jewish Publication Society of America, 1973), 3: 167-240; Yitzhak Baer, A History of the Jews in Christian Spain, trans. Louis Schoffman, 2 vols. (Philadelphia: Jewish Publication Society, 1978), 1: 39-77. On the transition from Arabic to Hebrew, see Consuelo López-Morillas, 'Language,' in The Literature of AlAndalus, ed. María Rosa Menocal, Raymond P. Scheindlin, and Michael Sells (Cambridge: Cambridge University Press, 2000), 41-6.

${ }^{16}$ See Petrus Alfonsi, Diálogo contra los judios, ed. Klaus-Peter Mieth, trans. Esperanza Ducay (Huesca: Instituto de Estudios Altoaragoneses, 1996), 6.
}

Author's Postprint version. Please cite published version: Wacks, David. "Conflicted Identity and Colonial Adaptation in Petrus Alfonsi's Dialogus Contra Judaeos and Disciplina Clericalis.” Marginal Voices: Studies in Converso Literature of Medieval and Golden Age Spain. Ed. Gregory B. Kaplan \& Amy Aronson-Friedman. Leiden: Brill, 2012.69-90. http://www.brill.nl/marginal-voices 
command of Latin ${ }^{17}$ and wrote treatises on various topics in the sciences, most of which have been regarded as mediocre by Andalusī standards, but were nonetheless groundbreaking in Latin. ${ }^{18}$ Petrus Alfonsi made available for the first time a wide variety of writings in mathematics, astronomy, and — most importantly for us - the short narrative tradition of the East. The Disciplina in particular was very successful, and sent ripples into medieval European narrative.

The role of Jews and conversos as cultural intermediaries is familiar to students of medieval and early modern Spanish literature. Petrus Alfonsi is a unique case among Spanish Jews and conversos whose literary output bridged Islamic, Jewish, and Christian literary culture. He precedes, but shares the historical stage, with two groups in particular: the Jewish translators of the $12^{\text {th }}$ and $13^{\text {th }}$ centuries, and the conversos of the $15^{\text {th }}$ and 16th. The first group of translators worked alongside their Christian colleagues under the auspices of Archbishop Raimundo of Toledo (late $12^{\text {th }} \mathrm{c}$.), who directed the translation of texts from Arabic into Latin, and Alfonso X the Learned (late $13^{\text {th }} \mathrm{c}$.), whose project produced texts in Castilian. ${ }^{19}$ These men were learned in Hebrew and Arabic scientific and literary tradition, and would have been fluent speakers of Iberian romance languages. As translators, they helped connect Latin readers with Arabic and Hebrew texts, but did not author original works in Latin. Therefore, their individual literary voices did not reach Christian audiences, and consequently little is known about their lives and characters; they remain shadowy figures, relegated to footnotes. ${ }^{20}$ Their work crossed cultural boundaries that they personally did not. To wit, while the Castilian translation of the Arabic Kalìla wa-Dimna was widely read and eventually appeared in print in Latin and Castilian, its anonymous translator did not accompany his work into the literary limelight.

Petrus Alfonsi, however, did cross these boundaries, and this crossing enabled him to make his voice heard in the Christian society that had suddenly and forcibly become his home in his middle age. If Moshé Sefardí found himself thrust into this new Christian world, Petrus Alfonsi made the decision to enter it of his own volition. Therefore, while by upbringing and education Petrus Alfonsi had a great deal in common with the translators who would later work for Archbishop Raimundo and Alfonso X, the fact of his conversion to Christianity makes his experience more relevant to studies of later conversos, and adds a psycho-social problematic to his work that is absent in that of his former fellow Jews who did not convert. The converso is very much present in his text.

\footnotetext{
${ }^{17}$ Marcelino Menéndez Pelayo dissents, claiming that Petrus Alfonsi's Latin was 'semitic.' Marcelino Menéndez Pelayo, Orígenes de la novela (Madrid: Editorial Nacional, 1943), 1: 62.

${ }^{18}$ On Petrus Alfonsi's transmission of Arabic learning to Christian Europe, see Tolan, Petrus, 42-72. On its relative mediocrity, see Alvárez, 'Petrus Alfonsi,' 286-7.

${ }^{19}$ Angel González Palencia, El Arzobispo Don Raimundo de Toledo (Barcelona: Editorial Labor, 1942); Gonzalo Menéndez Pidal, 'Como trabajaron las escuelas alfonsíes,' Nueva Revista de Filología Hispánica 5, no. 4 (1951); José S. Gil, La escuela de traductores de Toledo y los colaboradores judios (Toledo: Diputación Provincial de Toledo, 1985); David Romano Ventura, La ciencia hispanojudía (Madrid: Mapfre, 1992); Angel Sáenz-Badillos, 'Participación de judíos en las traducciones de Toledo,' in $L a$ escuela de traductores de Toledo (Toledo: Diputación Provincial de Toledo, 1996).

${ }^{20}$ González Palencia, Arzobispo, 121-2 and 65-6.
}

Author's Postprint version. Please cite published version: Wacks, David. "Conflicted Identity and Colonial Adaptation in Petrus Alfonsi's Dialogus Contra Judaeos and Disciplina Clericalis.” Marginal Voices: Studies in Converso Literature of Medieval and Golden Age Spain. Ed. Gregory B. Kaplan \& Amy Aronson-Friedman. Leiden: Brill, 2012.69-90. http://www.brill.nl/marginal-voices 
However, if Petrus Alfonsi is a converso, he is a converso of a different color. Dayle Seidenspinner-Núñez's warning against essentializing the converso experience bears repeating here: 'The real challenge for converso studies is to explore the full complexity and range of the converso presence in late medieval and early modern Spain, not to reduce or essentialize it for ideological purposes. ${ }^{21}$ The circumstances of his conversion set him apart from Spanish Jews who apostasized in the wake of the pogroms of 1391, the Disputation of Tortosa (1412-1413), and the Expulsion (1492). ${ }^{22}$ Petrus Alfonsi predates both of these groups by nearly three hundred years, and lived under quite different circumstances. He lived and died before the rise of the mendicant orders, to whose mission the conversion of Jews and Muslims was core. ${ }^{23}$ His community, while facing a new socio-political order under Christian rule, did not face the immediate threat of sectarian violence experienced by the Jews at the turn of the $15^{\text {th }}$ century, nor the systematic Inquisitorial persecutions at the turn of the $16^{\text {th }}$. We must consider that the personal and historical realities that led him to conversion were different, and this difference is present in his work, most notably in his relationship to his Andalusī Jewish past.

\section{The Dialogus contra judaeos}

The Dialogus is an anti-Jewish polemic in which Petrus Alfonsi attempts to prove the truth of Christianity and the errors of Judaism (and Islam) through logic. ${ }^{24}$ It is part of a healthy tradition of polemical texts in Latin which dates to early medieval Christianity. ${ }^{25}$ The Dialogus stands apart from later polemics such as Ramon Martí's Pugio fidei ('Dagger of Faith'), Peter the Venerable's Adversus judaeos, and Saint Thomas Aquinas'

\footnotetext{
${ }^{21}$ Dayle Seidenspinner-Núñez, 'Inflecting the Converso Voice: A Commentary on Recent Theories,' La Corónica 25, no. 1 (1996): 7.

${ }^{22}$ On the conditions of Petrus Alfonsi's apostasy, see Jeremy Cohen, 'The Mentality of the Medieval Jewish Apostate: Peter Alfonsi, Hermann of Cologne, and Pablo Christiani,' in Jewish Apostasy in the Modern World, ed. Todd M. Endelman (New York: Homes and Meier, 1987). For an overview of conversions and conversos in late medieval Spain, see David M. Gitlitz, Secrecy and Deceit: The Religion of the Crypto-Jews, Jewish Latin America. (Albuquerque: University of New Mexico Press, 2002), 3-34; On the period between 1391 and 1414, see José Amador de los Ríos, Historia social, política y religiosa de los judios de España y Portugal, 2 vols. (Buenos Aires: Editorial Bajel, 1943), 599-667; Baer, History, 2: 95-243. On the events surrounding the expulsion of 1492, see Amador de los Ríos, Historia, 160-91; Baer, History, 2: 424-43.

${ }^{23}$ On the proselytic activity of the mendicant orders among the Jews, see Jeremy Cohen, The Friars and the Jews: The Evolution of Medieval Anti-Semitism (Ithaca: Cornell University Press, 1982), 33-50; David Berger, 'Mission to the Jews and Jewish-Christian Contacts in the Polemical Literature of the High Middle Ages,' American Historical Review 91, no. 3 (1986).

${ }^{24}$ The Dialogus exists in 79 mansucripts (including fragments and translations). See Tolan, Petrus, 182-98. On the Dialogus, see John Tolan, 'Pedro Alfonso, precursor de la literatura apologética,' in Diálogo contra los judios, ed. María Jesús Lacarra (Huesca: Instituto de Estudios Altoaragoneses, 1996); 'Los Diálogos contra los judios,' in Estudios sobre Pedro Alfonso de Huesca, ed. María Jesús Lacarra (Huesca: Instituto de Estudios Altoaragoneses, 1996); Alvárez, 'Petrus Alfonsi,' 284-6.

${ }^{25}$ See, for example, A. Lukyn Williams, Adversus Judaeos; A Bird's-eye View of Christian Apologiae Until the Renaissance (Cambridge: Cambridge University Press, 1935); Gilbert Dahan, The Christian Polemic Against the Jews in the Middle Ages, trans. Jody Gladding (Notre Dame: University of Notre Dame Press, 1998).
}

Author's Postprint version. Please cite published version: Wacks, David. "Conflicted Identity and Colonial Adaptation in Petrus Alfonsi's Dialogus Contra Judaeos and Disciplina Clericalis.” Marginal Voices: Studies in Converso Literature of Medieval and Golden Age Spain. Ed. Gregory B. Kaplan \& Amy Aronson-Friedman. Leiden: Brill, 2012. 69-90. http://www.brill.nl/marginal-voices 
Summa contra gentiles in that Petrus confines himself to a strictly rational argument against the tenets of the Jewish religion, avoiding ad hominem attacks against the personal characteristics or behaviors of the Jews themselves. ${ }^{26}$ Barbara Hurwitz credits this even-handedness to Petrus Alfonsi's origins in the Jewish community, ${ }^{27}$ and the matter deserves a bit more nuancing. Manuel da Costa Fontes has demonstrated that Jewish lineage was a point of pride for many converso authors of the $15^{\text {th }}$ and $16^{\text {th }}$ centuries, and for this reason, the promulgation of the Estatutos de limpieza de sangre was 'particularly vexing. ${ }^{28}$ Petrus Alfonsi does not openly boast of or embrace his Jewish heritage; rather, he expresses his attachment to his Jewish cultural identity in subtler ways, perhaps subconsciously. In the Dialogus, the interior struggle between these two identities is played out by his two selves in dialogue, in what is arguably the first work of psychological drama in Western literature. In the introduction, Petrus Alfonsi explains how Moshé Sefardí sought him out upon receiving word of the apostasy/conversion of his alter ego:

A ternera igitur pueritiae aetate quidam michi perfectissimus adheresat amicus nomine Moyses, qui a primaeva aetate meus consocius fuerat et condiscipulus. Ad hunc cum pervenisset sermo, quod ego paterna lege relicta, Christianam delegissem fidem, relicto suae stationis loco, ad me festinus pervenit, in ipso adventu quendam vultum ferens hominis indignantis et increpans salutavit me more non amici, sed quasi alieni ... ${ }^{29}$

(Thus, since a tender age, a fast friend by the name of Moses was by my side; since my earliest years, he had been my companion and classmate. When word had reached him that I had abandoned our paternal law and chosen the Christian faith, he left his usual place, quickly came to me, his face that of an indignant man, and began by greeting me not in the manner of a friend, but as if I were a stranger ....)

Christian doctrine regarding conversion to Christ frames the experience as the resolution of a conflict, of a completion or a union of a 'divided self.' In the Catechism it is described metaphorically in terms of the return of the Prodigal Son. ${ }^{30}$ However, Petrus Alfonsi's experience suggests the opposite, that his conversion gave rise to an internal

\footnotetext{
${ }^{26}$ Barbara Hurwitz, 'Ambivalence in Medieval Religious Polemic: The Influence of Multiculturalism on the Dialogues of Petrus Alphonsi,' in Languages of Power in Islamic Spain, ed. Ross Brann (Bethesda, MD: CDL Press, 1997), 169.

${ }^{27}$ Hurwitz, 'Ambivalence,' 169.

${ }^{28}$ Manuel da Costa Fontes, The Art of Subversion in Inquisitorial Spain: Rojas and Delicado (West Lafayette, Ind.: Purdue University Press, 2005), 79. He gives several examples of converso pride in Jewish lineage in pp. 81-3.

${ }^{29}$ Petrus Alfonsi, Diálogo, 8. English translations from the Dialogus are mine, with reference to the Spanish of Esperanza Ducay.

${ }^{30}$ Luke 15: 11-24. See Catechism of the Catholic Church (Vatican City: Libreria Editrice Vaticana, 1994), 361, § 1493; Deal W. Hudson, 'A Catholic View of Conversion,' in Handbook of Religious Conversion, ed. H. Newton Malony and Samuel Southard (Birmingham, Ala.: Religious Education Press, 1992).
}

Author's Postprint version. Please cite published version: Wacks, David. "Conflicted Identity and Colonial Adaptation in Petrus Alfonsi's Dialogus Contra Judaeos and Disciplina Clericalis.” Marginal Voices: Studies in Converso Literature of Medieval and Golden Age Spain. Ed. Gregory B. Kaplan \& Amy Aronson-Friedman. Leiden: Brill, 2012. 69-90. http://www.brill.nl/marginal-voices 
separation between his Andalusī Jewish and Aragonese Christian identities so profound that it motivated him to publicly rationalize this conversion in writing, perhaps more for personal therapeutic benefit than for the edification of his readers.

Petrus Alfonsi clearly states that he writes the Dialogus in order justify his conversion. He argues that he was motivated not by material or political gain (as one might well suspect of a court physician whose prospects were ultimately limited by virtue of his being a Jew), but by the undeniable truth of Christian revelation and inconsistency and falsity of Jewish law:

Cumque notum esset Iudeis, qui me antea noverant, et probaverant peritum in libris prophetarum et dictis doctarum, partem etiam, licet non magnam, habere omnium libreralium artium, quod legem et fidem accepissem Christianorum et unus essem eorum, quidam eorum arbitrati sunt me hoc non fecisse, nisi quia adeo amnem abieceram verecundiam, quod et deum et legem contempscram. Alii vero proterea me fecisse dicebant, quod non, ut decuerat, prophetarum et legis verba intellexissem. Alii autem vanae gloriae imputabant et me hoc fecisse calumpniabantur ob honorem seculi, eo quod Christianorum gentem ceteris omnibus superesse conspicerem.

Hunc igitur libellum composui, ut omnes et meam cognoscant intentionem et audiant rationem, in quo omnium aliarum gentium credulitatis destructionem proposui, post hec Christianum legem omnibus prestantiorem esse conclusi. ad ultimum etiam omnes cuiuslibet Christiane legis adversarii obiectiones posui positasque pro meo sapere cum ratione et auctoritate destruxi.

Librum autem totum distinxi per dialogum, ut lectoris animus promptior fiat ad intelligendum. In tutandis etiam Christianorum rationibus nomen, quod modo Christianus habeo, posui, in rationibus vero adversarii confutandis nomen, quod ante baptismum habueram, id est Moysen. ${ }^{31}$

(And, as it was known by the Jews who knew me previously and who regarded me as an expert in the books of the Prophets and sayings of the doctors, and in part, albeit not large, of the liberal arts, that I had accepted the law and faith of the Christians and that I had become one of them, some of them thought that I had only done so because at that point I had shed all modesty, for I hated God and his law. Others said that no, I had done it because I had not understood well the words of the Prophets and the law. Still others attributed it to vainglory, and insulting me by [implying my] worldliness, said that I had seen that the Christian people were surpassing all the others.

\footnotetext{
${ }^{31}$ Petrus Alfonsi, Diálogo, 6-7.
} 
Therefore, I composed this book, so that all might know my intentions and hear my reasoning, in which all I proposed the destruction of the belief of all other peoples, that they might quickly conclude that the Christian law is superior to all others. Finally, I also expound all of the objections of any adversary of Christian law, and once expounded, I refuted them according to my knowledge, with reasoning and authorities.)

Critics are in disagreement as to the specific motives of Petrus Alfonsi's conversion, and although we may speculate as to its sincerity, his very thorough rationalist assessment of both faiths confirms that it was a deliberate, well-thought out act. ${ }^{32}$ Despite his protestations, and particularly in light of the fact that the King himself was his godfather, one cannot help thinking that contemporary politics played an important part in bringing Moshé to the baptismal font.

Petrus Alfonsi's decision to write his polemic in dialogue is what makes it possible for him to project his inner conflict onto the page. However, the dialogue genre is hardly an innovation on the part of Petrus Alfonsi. It was widely cultivated in Arabic poetry and especially in Arabic philosophical texts by both Jews and Muslims. ${ }^{33}$ In Christian literature, it would become increasingly popular in both Latin and the Romance vernaculars during the $15^{\text {th }}$ and $16^{\text {th }}$ centuries. ${ }^{34}$ However, the dialogue between self and self is unique to Petrus Alfonsi's Dialogus, which begs the question: why did Petrus Alfonsi cast himself as his own interlocutor, and what does this auto-dialogic format mean in the context of his conflicted identity as a converso? Why put his identity crisis on display? One possible answer is that in making his inner dialogue public he sought to satisfy those skeptics (whom he mentions in the prologue) of the sincerity of his conversion. Perhaps he felt that his Jewish self would gracefully retire into obscurity after being defeated publicly in a fair fight, just as an imaginary friend might disappear after being convinced he or she was not real.

We have a clue to this mystery in the decidedly anti-climactic conclusion of the Dialogus. Where one might logically expect Petrus Alfonsi's superior logic to result in

\footnotetext{
${ }^{32}$ On the question of Petrus Alfonsi's motives for converting, see Cohen, 'Mentality,' 27-8; David Romano, 'Mošé Sefardí (= Pedro Alfonso) y la ciencia de origen árabe,' in Estudios sobre Pedro Alfonso de Huesca, ed. María Jesús Lacarra (Huesca: Instituto de Estudios Altoaragoneses, 1996), xv; Tolan, Petrus, 13.

${ }^{33}$ On the dialogue in Arabic poetry, see Encyclopedia of Arabic Literature, ed. Julie Scott Meisami and Paul Starkey, 2 vols. (London: Routledge, 1998), 191; Julie Scott Meisami, Structure and meaning in medieval Arabic and Persian poetry: Orient Pearls (London: RoutledgeCurzon, 2003), 139 and 211-3. On its cultivation in $11^{\text {th }}$-century al-Andalus, see $E I$, 'Ibn Burd.' On its use in works of kalām (rationalist philosophy), especially in the $11^{\text {th }}$ and $12^{\text {th }}$ century, see Haggai Ben-Shammai, 'Kaläm in medieval Jewish philosophy,' in History of Jewish Philosophy, ed. Daniel H. Frank and Oliver Leaman (London: Routledge, 1997), 122.

${ }^{34}$ On the dialogue in Spanish humanism, see Jeremy Robbins, 'Renaissance and Baroque: Continuity and transformation in early modern Spain,' in The Cambridge History of Spanish Literature, ed. David T. Gies (Cambridge: Cambridge University Press, 2004), 139-41. On the dialogue in Renaissance Italy, see David Marsh, The Quattrocento Dialogue: Classical Tradition and Humanist Innovation (Cambridge: Harvard University Press, 1980).
}

Author's Postprint version. Please cite published version: Wacks, David. "Conflicted Identity and Colonial Adaptation in Petrus Alfonsi's Dialogus Contra Judaeos and Disciplina Clericalis." Marginal Voices: Studies in Converso Literature of Medieval and Golden Age Spain. Ed. Gregory B. Kaplan \& Amy Aronson-Friedman. Leiden: Brill, 2012.69-90. http://www.brill.nl/marginal-voices 
Moshé's conversion, the text ends instead in a very polite draw, in which Moshé concedes that Petrus' reasoning is superior, but not enough so to bring the Jew into the fold:

M.- Multum certe suae tibi deus dedit sapientiae et te magna ilustravit ratione, quem vincere nequeo, immo tu obiectiones meas confutasti ratione.

P. - Hoc procul dubio donum est Spiritus Sancti, quem in baptismo recipimus, qui et corda nostra illuminat, ne falsum quid credere presumamus. Quod si tu, quod credimus, ipse etiam crederes et baptizari te feceres, eandem Spiritus Sancti illustrationem haberes, ut, quae vera sunt, cognosceres et, quae falsa, respueres. Nunc autem quoniam super te pietatem habeo, dei misericordiam imploro, ut Spiritus sui plenitudine te illustret et finem meliorem quam principium tibi prestet. Amen. ${ }^{35}$

(M.- It is certain that God gave you much wisdom and granted you great reasoning, things which I cannot defeat; yet on the contrary, it is you who refuted my objections with your syllogisms.

P. - Without doubt this is a gift from the Holy Spirit, that we receive in baptism and that iluminates our hearts so that we believe nothing false. And if you also believed that which we believe and were baptized, you too would have that same illumination from the Holy Spirit, that you might know truth and reject falsehood. And now, given that I feel pity for you, I implore God's mercy that he illuminate you with the fullness of his Spirit and that he grant you a better end than a beginning. Amen.)

Moshé concludes that Petrus is the better debater, but that human reason does not equal divine revelation. That is, Petrus may be able to argue adeptly for the superiority of Christianity, but the fact of his powers of reasoning being God-given does not make his arguments true. This argument is typical of the doctrine of free will (ikhtiyār) espoused by such rationalist Andalusī philosophers as Maimonides and Ibn Rushd (Averroes). ${ }^{36}$ They believed reason to be God's gift to humanity, but that humans are ultimately responsible for practicing it responsibly. ${ }^{37}$ Here, the author's ambivalence comes to the fore: Petrus claims superior logic, and Moshé concedes, yet remains intransigent on the question of Christian revelation. This means that Petrus Alfonsi either regarded the Jews

\footnotetext{
35 Petrus Alfonsi, Diálogo, 193.

${ }^{36}$ On rationalist philosophy (kalām), see Harry Austryn Wolfson, The Philosophy of the Kalam (Cambridge: Harvard University Press, 1976); Harry Austryn Wolfson, Repercussions of the Kalam in Jewish Philosophy (Cambridge: Harvard University Press, 1979). On the doctrine of ikhtiyār, or free will (a better translation is, perhaps, 'freedom of decision') see W. Montgomery Watt, Free Will and Predestination in Early Islam (London: Luzac, 1948); Encyclopedia Judaica CD-ROM Edition (Version 1.0), ed. Geoffrey Wigoder (Jerusalem: Keter; Judaica Multimedia, 1997), 'Free Will'; EI, 'Ikhtiyār.'

${ }^{37}$ See EI, "Ikhtiyār."
}

Author's Postprint version. Please cite published version: Wacks, David. "Conflicted Identity and Colonial Adaptation in Petrus Alfonsi's Dialogus Contra Judaeos and Disciplina Clericalis.” Marginal Voices: Studies in Converso Literature of Medieval and Golden Age Spain. Ed. Gregory B. Kaplan \& Amy Aronson-Friedman. Leiden: Brill, 2012.69-90. http://www.brill.nl/marginal-voices 
as impossibly stiff-necked, even in the face of his implacable logic, or that perhaps on some level, he himself doubted the effectiveness of rationalist argumentation in preaching to the unconverted. In either case, the conclusion of the Dialogus tells us that rationalist philosophy, the intellectual medium of Andalusī Jewish biculturality, cannot bridge Judaism and Christianity. While Moshé Sefardí was able to see-saw back and forth between Judaism and Islam, Petrus Alfonsi cannot do the same between Judaism and Christianity. Thus the discussion ends, leaving Petrus at the top of the see-saw, with no way to come down.

\section{The Disciplina Clericalis}

If the Dialogus is the story of an identity crisis, the Disciplina is its more felicitous, less problematic literary outcome. Andalusī Jewish biculturality depended on the Islamic doctrine of tolerance that was absent in Christianity. As we have seen in the Dialogus, it is difficult to write on religious heterodoxy in such an environment, but more secular material presents no such problem. Everybody loves practical philosophy, especially when delivered in amusing anecdotes and fables. This collection of stories and gnomic lore, with its combination of elements from Christian and Andalusī tradition, is Petrus Alfonsi's productive response to the challenge of being a converso intellectual in a colonial environment. The portrait of Petrus Alfonsi in the Dialogus is that of a man unable to satisfactorily reconcile his past and present selves. However, this same author who seems incapable of integrating his divided self in the context of religious discourse proves much more so in reconciling the literary cultures of his past and his present. In the Disciplina we see a Petrus Alfonsi who recalls the courtier-rabbis of al-Andalus, who moves between secular and religious, Arabic and Latin, Andalusī and Spanish. This transculturation of Andalusī $a d a b$ is Petrus Alfonsi's literary answer to the demise of Jewish biculturality under Christian rule. As it turns out, there is a way down from the up end of the see-saw - in the secular field. Petrus Alfonsi's secular solution to the end of Andalusī biculturality is transculturation, a strategy for negotiating literary expression in a colonial life between two cultures.

Transculturation is a term coined by the Cuban anthropologist Fernando Ortiz in his landmark study, Contrapunto cubano del tabaco y el azúcar. His thesis is that the culture of a colonized people does not disappear upon their adoption of a colonial culture, but rather engages the colonial culture in a process of transculturation that results in a unique new culture that bears elements of both but that is entirely its own. ${ }^{38}$ In the 1970 s and 80s, the Latin American literary critic Angel Rama used the term to demonstrate how South American authors consciously introduced elements of indigenous culture into their work in order to resist urban and Europeanizing literary values. He described the colonial author as a 'genial tejedor' ('good-natured weaver') who picks and chooses from among the repertoire of conquered and conqueror, selects and adapts, and so produces a new,

\footnotetext{
${ }^{38}$ Fernando Ortiz, Contrapunteo cubano del tabaco y el azúcar, ed. Enrico Mario Santí (Madrid: Cátedra: Música Mundana Maqueda, 2002).
}

Author's Postprint version. Please cite published version: Wacks, David. "Conflicted Identity and Colonial Adaptation in Petrus Alfonsi's Dialogus Contra Judaeos and Disciplina Clericalis.” Marginal Voices: Studies in Converso Literature of Medieval and Golden Age Spain. Ed. Gregory B. Kaplan \& Amy Aronson-Friedman. Leiden: Brill, 2012.69-90. http://www.brill.nl/marginal-voices 
unique literature neither indigenous nor colonial. ${ }^{39}$ More recently, Mary Louise Pratt has written of transculturation in the context of colonial and postcolonial travel narrative in her book, Imperial Eyes. For Pratt, the term transculturation describes 'how subordinated or marginal groups select and invent from materials transmitted to them by a dominant or metropolitan culture. ${ }^{40}$

There are, granted, some crucial differences between $20^{\text {th }}$-century Latin America and $12^{\text {th }}$-century Aragon, hinging on questions of political power and cultural prestige. First, the Andalusī culture that Petrus Alfonsi represented to the dominant colonial power of Christian Aragon was quite prestigious by Western European standards. Though Islam and Judaism were abhorred by Spanish Christians, the science and philosophy of Andalusī Muslims and Jews were highly prized. By contrast, many Spanish conquistadores considered the indigenous Americans to be subhuman and barely capable of reason. This inversion notwithstanding, the power dynamic between conquered Andalusī and conquering Spanish Christian is colonial, and Petrus Alfonsi works both the prestige of Andalusī learning and the power of Christian rule to his advantage. Therefore, while the mechanism of transculturation as described by Ortiz and Rama is similar in the Disciplina, the terms of engagement are somewhat different.

Although the Disciplina clericalis may have been completely novel to Latin audiences in terms of its narrative structure and its use of sources drawn entirely from the Arabic and Hebrew tradition, Petrus Alfonsi was simply introducting into Latin literature a well-established genre of courtly literature from Arabic tradition: $a d a b .^{41}$ The Arabic word $a d a b$ boasts a broad semantic field of meanings and usages that includes 'proper conduct' or 'manners' as well as 'education' or 'literature. ${ }^{42}$ In the early period of Islam, through roughly the eighth century, an $a d \bar{l} b$, or cultured man, was one who had mastered the poetic and anecdotal traditions of the pre-islamic jāhilizyya age. ${ }^{43}$ During the cultural flowering of the $A b b a \overline{s i d}$ period $\left(8^{\text {th }}-9^{\text {th }}\right.$ c.) it came to mean one who was versed not only in Arabic poetics but also in the wisdom literature and brief narrative absorbed from Indian and Persian traditions, as well as the practical philosophy of the Greeks. ${ }^{44}$ By the beginning of the $9^{\text {th }}$ century, $a d a b$ also came to signify such social graces as the ability to entertain others with verse, amusing anecdotes, and of course, tales and fables. ${ }^{45}$ At times, what made these anecdotes and tales amusing was their claim to didactic authority. That is, many of the stories that were counted as adab literature were not intended as serious moral lessons, but as ironically didactic bits of entertaining narrative. ${ }^{46}$ It is also important to remember that the narrative genres that eventually came to be recognized as

\footnotetext{
${ }^{39}$ See Angel Rama, Transculturación narrativa en América Latina (Mexico City: Siglo Veintiuno, 1982), 19.

${ }^{40}$ Mary Louise Pratt, Imperial Eyes: Travel Writing and Transculturation (London: Routledge, 1992$), 6$.

${ }^{41}$ On $a d a b$ literature, see S.A. Bonebakker, 'Adab and the Concept of Belles-Lettres,' in 'Abbasid BellesLettres, ed. Julia Ashtiany, et al. (Cambridge: Cambridge UP, 1989).

${ }^{42}$ Bonebakker, 'Adab,' 25.

${ }^{43}$ See EI, 'Djāhilīyya.'

${ }^{44}$ EI, 'Adab.'

${ }^{45}$ Bonebakker, 'Adab,' 23.

${ }^{46}$ Petrus Alfonsi, Scholar's, 20.
}

Author's Postprint version. Please cite published version: Wacks, David. "Conflicted Identity and Colonial Adaptation in Petrus Alfonsi's Dialogus Contra Judaeos and Disciplina Clericalis." Marginal Voices: Studies in Converso Literature of Medieval and Golden Age Spain. Ed. Gregory B. Kaplan \& Amy Aronson-Friedman. Leiden: Brill, 2012.69-90. http://www.brill.nl/marginal-voices 
$a d a b$ were introduced as part of the adaptation of Persian material into Arabic literature that characterized the Abbasid period. ${ }^{47}$

Eventually, there appeared compilations of adab literature, miscellanies and anthologies that served as handbooks for courtiers aspiring to eloquence and witty discourse of the type that facilitate one's career. It was the $10^{\text {th }}$-century Andalusi author Ibn 'Abd al-Rabbih who first consciously referred to his own writing as $a d a b .^{48}$ In his $a l$ 'Iqd al-farid, or 'Unique necklace' he writes the following:

I have composed this book and selected its gems from the best gems of $a d \bar{a} b$; it is the result of the compilers of clarity, and was the gem of gems and the pith of piths; surely within it is compiled the choicest of selections, the best of anthologies, a mantle upon the breast of every book; it has no equal among the captured aromas of the sayings of the learned, and the achievements of the sages and the literati ( $\left.u d a b \bar{a} \bar{a}^{\prime}\right)$. And the selection of wise sayings is more difficult than their composition, for they have said: 'man's freedom of decision (ikhtiyār) is the ambassador of his intelligence., 49

In his introduction to the Disciplina, Petrus Alfonsi echoes Ibn 'Abd al-Rabbihi's description of the author of $a d a b$ as a compiler and anthologizer, listing the various sources upon which he draws:

...libellum compegi partim ex proverbiis philosophorum et suis castigationibus, partim ex proverbiis et castigationibus Arabicis et fabulis et versibus, partim ex animalium et volucrum similitudinibus. ${ }^{50}$

(...I have put together this book, partly from the sayings of wise men and their advice, partly from Arab proverbs, counsels, fables, and poems, and partly from bird and animal similes.) ${ }^{51}$

As an Andalusī intellectual, Petrus Alonsi would have been well-versed in $a d a b$ and in all likelihood would have known Ibn `Abd al-Rabbih's work. However, compiling a work of $a d a b$ in al-Andalus, where it was part of an established tradition, is one thing; introducing such a book in Christian literary culture is another. Petrus Alfonsi did not write the Disciplina in a political vacuum; his motives for conversion were most likely political (at least in part). His ability to thrive during a time of colonial conquest and social upheaval is part of his genius, is borne out in the pages of the Disciplina. The

\footnotetext{
${ }^{47}$ On the legitimation of fiction in Classical Arabic literature, see Rina Drory, Models and Contacts: Arabic Literature and its Impact on Medieval Jewish Culture (Leiden: Brill, 2000), 37-47.

${ }^{48}$ Bonebakker, 'Adab,' 28.

${ }^{49}$ Ibn 'Umar Ahmad ibn Muhammad Ibn `Abd al-Rabbihi, al- 'Iqd al-farīd, ed. Ahmad Amīn, Ahmad AlZayn, and Ibrāhīm al-Ibyārī, 7 vols. (Beirut: Dār al-Kitāb al-`Arabī, 1982), 1: 2, translation mine.

${ }^{50}$ Petrus Alfonsi, Disciplina, 2.

${ }^{51}$ Petrus Alfonsi, The Disciplina, 104.
} 
(re)conquest of al-Andalus was most certainly a colonial project, motivated primarily by material concerns but justified by the idea that the Christians of Castile-León and Aragon had a historic right to the whole of the Iberian peninsula by virtue of their 'Visigothic' lineage. ${ }^{52}$ In this spirit, the Disciplina is a transculturation of the purely secular $a d a b$ literature of the colonized Andalusīs in a lightly Christianized, Latin format. It is an excellent example of the transculturation of Andalusī learning into Christian society.

Confident that his store of Andalusī knowledge is in high demand, and writing in Latin as a Christian of very high standing, the 'genial tejedor' Petrus Alfonsi is at liberty to pick and choose his materials. His effort to frame his work in terms of Christian morality is decidedly pro forma, and mostly passive. His work contains no material of specifically Christian provenance, and does not illustrate Christian doctrine nor recount miracles of Saints. The only specific references to Christianity are found in the prologue, in which he clearly states that his intent is not necessarily to promote Christian doctrine, but rather to introduce readers to those elements of Andalusi $a d a b$ that do not contradict or offend the Christian faith. ${ }^{53}$ Of the thirty-odd stories in the collection, there are only three that deal with moral issues, and even these fit equally well within the framework of Islam, Judaism, or Hinduism. ${ }^{54}$ Petrus Alfonsi, therefore, was a medieval version of Rama's 'genial tejedor,' who picks and chooses from his warehouse of Andalusī learning, fitting it into his understanding of a suitable Christian framework. In doing so, he demonstrates the rational selectivity that for Ibn `Abd al-Rabbihi is the essence of $a d a b$, and for Rama is characteristic of transculturation in narrative fiction.

This disclaimer having been made, he repeatedly emphasizes the Arabic (and not Muslim) authenticity of his material, separating it from the context of Islamic and Jewish al-Andalus in which he learned it. As an Arabized Jew living in an Islamic society, this distinction would have been second nature for Moshé Sefardí, and serves Petrus Alfonsi well. Conscious of the prestige accorded to Arabic in $12^{\text {th }}$-century Aragon, Petrus Alfonsi deliberately calls attention to the fact that he wrote the work in a language other than Latin (we can only assume it to be Arabic), and subsequently translated it. ${ }^{55} \mathrm{He}$ wants his audience to know that his work is not merely a Latin composition of remembrances from an Andalusī education, but an original anthology of 'authentic' Arabic lore. To this end, he puts many of the wise sayings and exempla in the mouths of known figures from

\footnotetext{
52 See José Antonio Maravall, 'La idea de la Reconquista en España durante la Edad Media,' Arbor 101, no. XXVII (1954): 269-87; Peter Linehan, History and the Historians of Medieval Spain (Oxford: Clarendon Press, 1993), 95-127; Joseph F. O'Callaghan, A History of Medieval Spain (Ithaca: Cornell University Press, 1983), 4-7. On colonialism in medieval Iberia, see Robert Ignatius Burns, Islam Under the Crusaders, Colonial Survival in the Thirteenth-century Kingdom of Valencia (Princeton: Princeton University Press, 1973); Elena Lourie, Crusade and Colonisation: Muslims, Christians, and Jews in Medieval Aragon (Aldershot, Hampshire, UK; Brookfield, Vt.: Variorum, 1990). Repobladores ('resettlers') are described quite plainly as 'colonists' in Angus MacKay, Spain in the Middle Ages: From frontier to empire, 1000-1500 (New York: St. Martin's Press, 1977), 36.

${ }^{53}$ See Petrus Alfonsi, Disciplina clericalis, ed. Alfons Hilka and Werner Söderhjelm, vol. 28, Acta Societatis Scientiarum Fennica (Helsinki: 1911), 2. For English translation, see Petrus Alfonsi, Scholar's, 34.

${ }^{54}$ Petrus Alfonsi, Scholar's, 20.

${ }^{55}$ See Petrus Alfonsi, Disciplina, 2; for English translation, see Petrus Alfonsi, The Disciplina, 104.
}

Author's Postprint version. Please cite published version: Wacks, David. "Conflicted Identity and Colonial Adaptation in Petrus Alfonsi's Dialogus Contra Judaeos and Disciplina Clericalis." Marginal Voices: Studies in Converso Literature of Medieval and Golden Age Spain. Ed. Gregory B. Kaplan \& Amy Aronson-Friedman. Leiden: Brill, 2012.69-90. http://www.brill.nl/marginal-voices 
Arabic lore such as Idriss and Luqmān. ${ }^{56}$ Other times he attributes material to anonymous Arabs, either poets or fathers instructing their sons. ${ }^{57}$ Some of the exempla are set in the Arab world, ${ }^{58}$ including Spain. ${ }^{59}$ By contrast, the only place in the Latin world he mentions by name is Rome. ${ }^{60}$ By any reckoning, the Disciplina is intended to be representative of Andalusī learning, and not as a work of Christian literature per se.

Petrus Alfonsi's transculturation of $a d a b$ is not limited to sources or to introduction of narrative material previously unknown to Latin audiences. Eberhard Hermes has noted that the Disciplina presents a social world not typically portrayed in medieval Christian literature, a world of cities, merchants, and artisans in which there is but a single mention of a knight. ${ }^{61}$ Petrus Alfonsi recontextualizes this cosmopolitan world of commerce and practical strategies for material success, weaving its warp into Christian woof of Latin didactic literature, thus living up to Rama's ideal of the 'genial tejedor' ('good-natured weaver') of Andalusī adab on a Latin frame.

Students of late medieval and early modern conversos can learn a great deal from the life and work of Petrus Alfonsi, particularly in thinking of his writing as a reaction to the colonial times in which he lived. In his Dialogus we see the result of the breakdown of Jewish Andalusi biculturality following the conquest of Aragon by the Christians, and the resulting torment of the converso of convenience who is forever torn between Jewish and Christian identity. ${ }^{62}$ Such conflict, while personally painful, can be quite productive culturally. The Disciplina is the literary product of a converso who bridged the Andalusī and Spanish intellectual worlds, and who chose to make lemonade with the lemons that fell from the sky above newly Christian Aragon. While the Dialogus ends in a standstill, with Petrus unable to convince Moshé to let go of their common past, the Disciplina is more successful in reconciling Moshé and Petrus. His experience shows us that in reconciling conflicted identity and negotiating difference, storytelling may succeed where rational debate does not.

\footnotetext{
${ }^{56}$ Petrus Alfonsi, Disciplina, 2 and 3; The Disciplina, 104 and 05.

${ }^{57}$ Petrus Alfonsi, Disciplina, 2, 3, 7, 9, 26, 31, 33, and 39; The Disciplina, 104, 06, 12, 13, 16, 35, 42-43, and 44.

${ }^{58}$ Petrus Alfonsi, Disciplina, 4 and 27; The Disciplina, 107 and 36.

${ }^{59}$ Petrus Alfonsi, Disciplina, 20; The Disciplina, 128.

${ }^{60}$ Petrus Alfonsi, Disciplina, 17; The Disciplina, 124.

${ }^{61}$ Hermes also notes that the topoi of courtly love, chivalry, and Marian worship are all conspicuously absent in the Disciplina. See Petrus Alfonsi, The Disciplina, 6.

${ }^{62}$ Critics have debated the question of converso angst for some time. For a summary of the debate, see Amy Aronson-Friedman, 'Identifying the Converso Voice' (Doctoral Dissertation, Temple University, 2000), 13-20.
}

Author's Postprint version. Please cite published version: Wacks, David. "Conflicted Identity and Colonial Adaptation in Petrus Alfonsi's Dialogus Contra Judaeos and Disciplina Clericalis." Marginal Voices: Studies in Converso Literature of Medieval and Golden Age Spain. Ed. Gregory B. Kaplan \& Amy Aronson-Friedman. Leiden: Brill, 2012. 69-90. http://www.brill.nl/marginal-voices 